\title{
The colonial discourse of domination: Notes on the Christian religious contact among the indigenous of Paraná, Brazil.1
}

Grazieli Eurich²

DOI - 10.25160/v5i2.ga.6

In 1858, intimidated by this and other defeats, they came forward in large numbers to the military authorities of the Yathahy Colony, seeking to obtain a treaty with the imperial government, with which the villages of San Gerônimo and San Pedro de Alcântara were to be founded. Those who were destined to the former village of San Gerônimo still live in it, and they are docile and industrious, thanks to the efforts of Frey Luis de Cemitile. But those in the latter village, disgusted by the missions that had touched them, abandoned it, living peacefully today in the forests of Tibagy and Ivahy valleys. Those living in 'savage' state but who have not yet done any damage, they escaper to the jungles of Piquiry and the lower Ivahy and Yguazú (Ambrosetti 1895: 306.) ${ }^{3}$

The fragment above is by the Argentine Juan B. Ambrosetti and was taken from its publication in the Revista del Jardin Buenos Aires Zoo in 1895. By studying the Kaingang Indians of San Pedro (Missions), the author cites the Kaingang from Paraná and especially those from Ivaí. The above is indicative of a colonial discourse even in a period of Brazilian

1The work is linked to an ongoing research called "The Faith that Moves the Indians: The Monk São João Maria and his 'Echoes' in Kaingang Struggles for Land in the Interior of Paraná, in 1923," a PhD project in History from the Federal Rural University of Rio de Janeiro and Doctoral stage 'sandwich' fellowship from the Brazilian CAPES program at Southern Illinois University, Carbondale, IL, USA. I thank the co-advisor, Professor Jonathan Hill, by the contributions and gentle revision of this text.

${ }^{2}$ Universidade Federal Rural do Rio de Janeiro (UFRRJ), Southern Illinois University Carbondale (SIU)

3 Original excerpt in Spanish: En 1858, acobardados por esta y otras derrotas, se presentaron em gran número a las autoridades de la Colonia Militar de Yathahy, procurando entrar em tratos com el gobierno imperial, el que fundó com ellos las aldeas San Gerónimo y San Pedro de Alcántara. Los que fueron destinados a la primera, vive aún em ella, siendo mansos y industriosos, gracias a los esfuerzos de Frey Luis de Cemitile, pero los de la segunda, disgustados del misioneo que les tocó, la abandonaran, vivendo hoy pacificamente en los montes de los valles de Tibagy y Ivahy. Los que viven em estado salvaje, pero aún no han hecho daño, recorren las selvas del Piquiry, bajo Ivahy y Yguazú. (Ambrosetti 1895:306)

RRASILIANA- Journal for Brazilian Studies. Vol. 5, n.1 (Nov, 2016). ISSN 2245-4373.

(c) (1) 
Republican enthusiasm. The Indian, the 'other', is gentle and industrious if they accept the missionaries efforts, however the Indian who leaves the intent of the religious village, is a 'savage' that races to the forests.

The 'Gentiles' were to be treated as blank sheets of paper that should be filled out by missionaries and their Christian morality. Servants of only one god and civilized, they would collaborate with the attempts of colonization in the exploitation and expropriation of their territory. As can be seen through the quotation from Ambrosetti, even as late as the nineteenth century, this discourse was valid as a justification for establishing religious villages of the Empire, a form of discourse that has persisted for centuries and continues today.

The text "The fickleness of the Savage Soul: Revenge and war, a barrier to catechizing the Tupinambá", by anthropologist Eduardo Viveiros de Castro, addresses the inconsistencies of attempts to convert the Tupinambá in the sixteenth century through the reports of chroniclers and missionaries.

In the context of the missionaries' colonial discourse, 'bad' customs such as war and revenge -- with cannibalism as its ultimate form -- represented obstacles to the intent of the missionaries. For Viveiros de Castro, these customs were seen as reasons for the fickleness: "the missionaries did not see that the 'bad habits' of the Tupinambá were their true religion, and that their fickleness was the result of deep adherence to a set of full right religious Jesuit beliefs" (Viveiros de Castro 2002:182).

How to make a convenient reading of other customs, categorizing them as different, exotic, and abominable? By with drawing Tupinambá cannibalism from all senses that the Indians gave it and through repetition of the abominable, colonial discourses were legitimized. But, as the text emphasizes, this was not easy precisely because of the Tupinambás fickleness. "The warrior vengeance is the source of all bad habits: cannibalism, polygamy, drunkenness, accumulation of names, honors, everything seems to revolve around this theme" (Viveiros de Castro 2002:226).

Using the same colonial discourse of Christianity and civilization, the Spanish founded three cities and fifteen Jesuit missions in the sixteenth century in what is now the southern Brazilian state of Paraná. By the Treaty of Tordesillas between Portugal and Spain in 1494, the region belonged to the Spaniards. "The region, called Guairá, was populated mainly by Guaraní people and Jê[...] The Guairá had the Paranapanema River as their limit 
to the north, the Iguaçu to the south, the Paraná on the west, and Guarayrú sierra to the east" (Parellada 2013: 251).

The indication of Jê groups (language family of Kaingang) living in these missions is highly significant. "Most of the missions were created with Guaraní Indians, only four had people of Jê language family, which are the missions of San Antonio and San Miguel founded with Camperos Indians, and Concepción de Nuestra Señora de Guañaños and San Pedro with Gualachos Indians" (MCA I, 1951). In the early seventeenth century, documents describe underground structures and linguistic and cultural differences between these groups and the Guaraní (Parellada 2013: 253-254).

Catechizing the indigenous peoples would be important to conquer them without armed conflict, since the numerical superiority of the Indians could pose a real danger to the objectives and lives of the Spaniards, as stated in the quote below.

In 1607, the governor of Paraguay Hernandarias de Saavedra, in his report to Philip III, stresses the importance of catechizing the indigenous tribes of the Guairá because they were too numerous in relation to the amount of Spanish, because in this way they could conquer the region without arms. Still in the letter, Hernandarias informs that Ciudad Real and Villa Rica there were respectively 30-100 Spanish settlers, around, there were about 150,000 Indians (Taunay 1925: 284-305 Apud Parellada 2009: 65).

The missions were created in 1610, and they had their own materials for teaching civility and catholicism. "The evangelization of the Indians was made with the help of books rich in images, which showed the life of Jesus Christ: childhood, public life, in addition to the Passion and Resurrection"(Parellada 2013:254).

In a speech that portrayed the other as a degenerate, the European, or "civilized" way of life, was the objective to be achieved. "To the people or settlements of Indians who live according to their former customs in jungles, mountains, and valleys, and along the creeks hidden in three, four or more peoples, reduce them to the diligence of priests in the not small villages and to civilized and human political life, also benefiting from the cotton with which they dressed, because in general they lived in the nudity" (Montoya 1985: 34, emphasis added). 
The passage above denies even humanity to the Indian who has not received the "light" of civilization, which is precisely the intention of the colonial discourse. Thus, the main objective of the missions is fulfilled: to catechize the Indians, baptizing them and instructing them in the Catholic faith; to teach new forms of labor, as well as music and visual arts; to assist in the recovery of the sick from influenza and smallpox epidemics and ministering the sacrament of extreme unction to the dead; to convince the Guarani to abandon polygamy and anthropophagy; to mitigate the conflict between Spaniards and Indians; and to defend the Spanish Crown to by denouncing and fighting against Paulista raids to capture Indians in Guairá.

The main objective in the catechesis of the Indians in the Spanish missions is to obtain manual labor. Manual labor through the encomienda system was essential for the survival a colony where there were no mineral riches to send to the crown. Indigenous manual labor was also the source of conflict between the missionaries and the Spanish colonists and later one of the reasons that led to destruction of the reductions by the Paulista Bandits and o the imprisonment of indigenous workers. "In this regard, the Indian was not the only motive of interest for the Province of Paraguay settlers, but also of Spanish and Portugueses jesuits, besides the Paulista Bandits. For these, indigenous manual labor constituted the basis for economy growth on the plateau "(Monteiro 1994: 58).

The foundation of villages facilitated the exploitation of indigenous labor in the encomienda system. An encomienda "is a colonial institution that is characterized as the granting of the Catholic Monarchs to the Spanish conquistadors and their descendants, who had a prominent role in the service of the Crown. It was comprised of a territory and the population living in it. In exchange, those receiving such favors must protect indigenous laborers and instruct them in the religion"(Damo 1994:75 Apud Oliveira 2003: 63).

About the foundation of Villa Rica in the Guairá region, historian Oséias Oliveira writes, "despite the desire for wealthy precious metals, we only found quartz and amethyst, the only stones of any value that could result from the exploration of the locality. It remained thus for them to turn their attention to another activity which seemed to have greater possibilities for material success, the intensive exploitation of indigenous manual laborers"(Oliveira 2003: 61).

The establishment of the encomienda is linked to occupation of the territory, foundantion of new settlements and especially "the incorporation of the Indian in the social and religious colonial system and establishing them, as a fundamental key in the fragile 
guairenha economy in the late sixteenth century, reaching even, to constitute of the 'wealth of the hinterland "(Oliveira 2003: 68).

They refuse the indigenous customs, they impose new customs, such as the Catholic religion, for thus, the Indians serve as workforce and defense. The civilized Indian didn't represent danger, the Christian Indian helps maintain the defense of the territory, the Indian's workforce for the mission and to the colony. The colonial discourse is not only used to convert souls to Christianity, for catechesis, the colonial discourse legitimizes the actions that will have political and economic purposes, "just watch carefully the name of the new town to realize the interests that moved the occupation of Guairá: Villa Rica del Espíritu Santo. Advantageous materials combined with a mindset that seeks justification in the religious sphere "(Oliveira 2003: 60).

When writing this text I talked of the intent of colonial discourse using the Religion for their purposes, and about how the indigenous reinterpreted the contact and how they resisted the colonial power of the domination of land, bodies and minds, is another issue that was not addressed by this paper but cannot fail to be appointed.

The colonial discourse continued to be used in the creation of religious settlements in the period of the Brazilian Empire (circa 1822 to 1889). Imperial Decree number 426 of 1845 called for regulating the service of the Mission of Evangelization and Civilization of the Indians. However, indigenous settlements during the Empire period represented a radical discontinuity in the long-term history of Amerindian catechesis in Brazil.

The program of Catechesis and Civilization of the Indians explicitly approximated of the indigenist theses of the Pombal period, and was in this sense a reinterpretation of the Pombalino Directory of 1775, in the respect to the emphatic orientation in favor of the mixture of Indians with the other inhabitants of the towns and villages, to encouraging migration of settlers to the areas traditionally inhabited by Indians, and the implementation of forced relocations of the Indians. Thus if the inspiration of the village format of the Indians came from the Jesuit mission, distances built in relation to its model were remarkable (Amoroso 2014: 74-75).

In this Empire period, it adds a miscegenation project and settlement of the territory by settlers. The Empire settlements were thought of as transient, in order to attract the Indians, 
hold them, until the Indians themselves mixed with the Christian population such that afterwards these villages were dismantled.

There in the indigenous village in Itambacuri (1873), Minas Gerais, the project of mixture or miscegenation was particularly noticeable. Mixture as an instrument of civilization should be translated in indigenous settlements through religious conversion and transformation of Indians into Christians and the working poor. "The Christian project of 'construction of happiness' (Latour, 2004b), in Itambacuri passed like this for the transformation of Botocudos into poor, 'hardworking national mestizos"(Amoroso 2014: 58$59)$.

In the region of old Guairá, part of the province of Paraná since 1853, the village of St. Jerome was established in 1859, after the rapprochement between the Kaingang of São Pedro de Alcântara and the military outpost. It was located south on the road to Castro, twelve leagues away from San Pedro de Alcantara. It was administered between 1859 and 1867 by sertanista Joaquim Francisco Lopes and later by Friar Luís de Cimitille, a missionary who remained in the village until the 1880s (Amoroso 2014: 87).

There were in St. Jerome around 12 salaried employees, as well as a director, an overseer, a blacksmith, a carpenter and an elementary school teacher. The village housed a large number of settlers, had five buildings, work equipment consisting of houses for making flour, machines to process cotton, a water mill, a pottery-making facility, barns and sugarcane mill. "The population of Kaingang living in the village reached four hundred people in the 1880s, a number that grew in the winter, when Kaingang groups from other regions of the province, such as the Ivaí and Piquiri rivers, gathered near the settlements" (Borba 1908 Apud Amoroso 2014: 88)

The work that was so important to the support of the Jesuit missions in the seventeenth century was also important for the purposes of religious settlements in the nineteenth century. To keep the Indians nearby, missionaries and authorities saw workplaces as the solution to engaging the Indians.

Thus, if the inspiration for the shape of the indigenous settlements of the nineteenth century was Jesuit and guidance was Pombalist in favor of the mixture of Indians with the other inhabitants, the vocation of settlements of Catechism and Civilization was to ensure that the Indians transform 
themselves in a relatively short time into poor free workers and targets of Christian philanthropy (Amoroso 2014: 76).

The work was also an important factor in religious enterprises contributing to the settlement of the colonists. Amoroso affirms previous studies on indigenous law how Manuela Carneiro da Cunha and Nádia Farage ${ }^{4}$ that showing that the purpose of indigenous villages was to meet demands for manual labor and infrastructural services for the concentration of indigenous inhabitants in the settlements. "From the perspective of mendicant friars, catechesis of the Indians has always been a government pretext: the purpose of indigenous villages was to maintain the viability of the settlement's infrastructure for the colonists" (Amoroso 2014: 89).

Not only land for the settlers, but a guaranteed proximity to religion, complete with security and manual labor, the latter, indigenous. "The indigenous villages signaled for Christian settlers to the security of the proximity of military colonies, the presence of the Church and the Christian priest, with the comfort of food supplied by farms maintained by salaried employees and the Indians" (Amoroso 2014: 90).

For the Indians the relationship with the state are established by the villages, founded on the legal protection and the definition of the right to land, conditioned by the savagery stage.

In the words of Moreira Neto (2005), with the creation of indigenous villages of the Empire, the most amazing expropriation of lands of indigenous peoples was undertaken. Created, the villages began to accept settlers in the vicinity of equipment, in lands declared unoccupied, and the sector formed by national and foreign colonists pleaded for the titling of lands in indigenous areas that became progressively occupied with the farming (Amoroso 2014: 76).

4 Farage, Nádia and Carneiro da Cunha, Manuela. 1987. "Caráter da Tutela dos Índios: Origens e Metamorfoses". In: Os Direitos do Índio. Ensaios e Documentos (Carneiro da Cunha, Org.), pp. 103-17), São Paulo, Editora Brasiliense. Carneiro da Cunha, Manuela. 1992. Legislação Indigenista no século XIX. Edusp, Comissão Pró-Índio de São Paulo, São Paulo, 1992. Carneiro da Cunha, Manuela. Política indigenista no século XIX. In: História dos índios no Brasil. (Carneiro da Cunha, Org.) São Paulo: Companhia das Letras. 
The pathway of vacant land in the territory led this settlement of colonists by the spoliation, a process which immediately initiated the establishment of settlements. "Raised on vacant land, these areas were titled in favor of migrant settlers and immigrants, who were the main targets of population policies of the period" (Amoroso 2014: 90).

In most cases, the administration of the village did not consider the demarcation of land for the Indians to be appropriate, using two main arguments: first, the Indians of the settlements were not exactly "autochthonous" and had been led by the authorities to occupy the land of the settlements; the second argument was that the Indians were nomadic, making it difficult to demarcate their lands (Amoroso 2014: 91).

What mattered to the Imperial policy towards the Indians was miscegenation, "the question of the Indians considered domesticated and confused with other rural workers was no longer to be regarded as a target of public policies" (Amoroso 2014: 78). However, if the Empire wanted to mix the Indians so that they ceased to be Indians and did not need to demarcate the territory, then it did not happen. "They did not predict that in the following decades the Guarani-Kaiowá Indians would remain Indians after the establishment of the indigenous settlements of Empire: as villagers, they could no longer technically be considered wild Indians" (Amoroso 2014: 71).

Concomitant with the intent of colonial discourse to use Religion for its own purposes, indigenous peoples reinterpreted the history of contact and withstood the force of the domination of their lands, bodies, and minds. In addition to the many indigenous strategies that emerged during the project of colonial expansion in the Jesuit missions of the seventeenth century, other strategies for demarcation of their territories in the religious settlements developed during the nineteenth century.

According to the historian Oséias Oliveira, in the mission villages of Guairá in the first decades of the seventeenth century, there was a process of cultural reinterpretation arising from interethnic relations between Indians and Jesuits. "The reductions were the space where they interpreted the cultural contact between Indian and Jesuit, which introduced a series of Christian symbols and values into native culture, which was forced to readapt itself in order to make sense of them" (Oliveira 2003: 116).

There is also an association process of elements of indigenous culture that help in the dialogue and in the reworking of culture received by the other. Louis Necker contributes to the understanding of Guarani conversions to Christianity in his study of the Franciscan activities in Paraguay, based on Alfred Metraux's studies of the prophets and messiahs in 
South America. Necker discerned an association that indigenous people made between the eloquent, lonely, and religious Jesuit and the shaman-prophet (Karai). To some extent, the role of the priest replaced that of the old religious leader, the shaman-prophet who wandered about preaching the pursuit of the land without evil among the villages (Necker 1990).

In addition to this association, it is important to point out that indigenous peoples perceived the benefits of a policy of protection, survival, and collective festivities. "Following the Jesuit or shaman, for the Indians it was a matter of verifying the advantages offered by these. Unlike Karai, of the priest could obtain protection from the Spanish encomenderos and São Paulo bandits, food provisions, and constant religious festivals "(Oliveira 2003:122).

We can not exclude the indigenous from the array of interests of the colonization process. If the colonial discourse had its objectives defined in the exploration of the 'new world', this 'new world' was not as new as the colonizers considered; it also asked for a return. "The Jesuits had a plan for humanization and Christianization of the indigenous people, while the Indians were interested mainly in material and cultural advantages that they could obtain through contact with the priests" (Oliveira 2003:123-124).

Not everything that was put to the indigenous people was willingly accepted by them. Some sacraments presented barriers to the intent of Christianization and required improvisation on the part of missionaries.

The fact that some indigenous to died after contact with priests, generated a problem for the missionaries, who were forced to readapt to this new situation. The Indians associated the Jesuit presence and the baptism of the sick as being responsible for their deaths. The priest becomes heavily criticized and blamed as the cause of death of the indigenous with their rituals. The salt used in the ritual becomes identificado as the venom with which the priest killed the Indian. Thus, the priest had to change his strategy of action, that is to wait a while without administering baptisms to the sick (Oliveira 2003:155).

Christian marriage was another of the sacraments which was met with great resistance from native peoples. Leaving behind the custom of polygamous marriage resulted not only in a 
decrease in the number of wives, but also a reduction in the size of kinship networks, which were the source of prestige as well as arms for agriculture and hunting. Monogamy was not interesting to the Indians and was a source of conflict with the missionaries. "That's what they the priests wanted to teach to the natives, but as this sacrament involved polygamy, a strong pattern of the Guarani culture, the Jesuits were to engage in a series of conflicts with indigenous leaders, because, [..] the Polygamy was prominent symbol in the village" (Oliveira 2003:153).

As briefly mentioned above, the Indians regarded the festivals, those moments of collective celebration, as one of the advantages of the missionary endeavor, but these events were reinterpreted. While apparently accepting cultural norms imposed by the Jesuits, the indigenous culture persisted and new meanings were coupled with the Christian culture that had brought these festivals and processions. "The Christian festival, where the meeting had the function of subject, formalization, and education, another purpose was elaborated by the Guarani, who made it a context for universality, freedom, and plenty [...] So the festival became a way in which the Indians made something other than what the Jesuit sought to obtain of the ritual actions, representations, and laws that were being imposed upon them" (Oliveira 2003: 162-163).

Indigenous people also resisted and reworked interethnic relations in the Capuchin settlements during the Empire in the 19th century. The letters of the Capuchin friars reveal that this relationship was not so successful for missionaries and underwent constant negotiations. "The Capuchin mission in Tibagi identified wild customs and great resistance to conversion to Catholicism, considering that the work of conversion would occur, perhaps, in time, with zero results so far" (Amoroso 2014:99).

In the settlements of the Empire, the indigenous people also sometimes resisted the imposition of religion by denying baptism, which is why the Capuchins preferred to convert the children. "The emphasis of the Capuchin program has tended to focus on the education of children, since it was considered that adults were impermeable to catechesis" (Amoroso 2014:100). Others denied baptism taking its as a sign of death, disease. The Capuchins showed in their letters that they were under no illusions about the sincerity of the Indians' conversion. When they accepted, the baptism often meant a way to obtain gifts from godparents; thus it was material interests which motivated the Indians to seeek out the sacrament. 
The Christian marriage, monogamy remained a hurdle for catechesis. The missionary Friar Timothy Castelnuovo admited in a letter to the provincial governor the impossibility of imposing Christian marriage in a polygamous system. "The simultaneous polygamy prevents this sacrament" (Castelnuovo 1888 Apud Amoroso 2014:97). The dispensation from the outlawing of indigenous marriages between first degree relatives was also requested so as not to drive indigenous people away from the Catholic mission. Thus, the missionaries also had to adapt their project, reworking it through concessions to the indigenous reality that they found. Marriage agreements and the funeral rites of the natives persisted but were held far away from the missionaries in the village São Pedro de Alcântara.

The Indians sought the settlements according to their needs, and not the contrary. "Most of the time the Kaingang remained in the araucaria forests, only visiting the settlements when they needed some merchandise or tools. To obtain them, they performed tasks. In the late 1870s, the Kaingang were producers of food and products derived from sugarcane" (Amoroso, 2014:88).

In the mission of Faxina in the province of São Paulo in 1862, friar Pacífico de Montefalco denounced the handling of the government Program of Catechesis and Civilization of the Indians; the Kaiowá Indians were pretending to be wild but were old acquaintances of their duties from the missions São Paulo and Paraná.

The Indians circled around the villages, following the trail of funds that were directed to one or another entity within the system. When necessary, the Indians made use of theatrical features, such as those used by the Guarani-Kaiowá's from Faxina, who presented themselves in bodypaint in the office of president of the province of São Paulo in the 1860s in order to show that they were in tune with the rules of Indian policy of the period, which preached that public funds demanded savage Indians (Amoroso, 2014: 79).

The Kaingang also engaged in the politics of the Empire and went to Curitiba, capital of the Paraná province, in order to reclaim their ancestral lands. It was during the religious settlements of the Empire that the first indigenous land was demarcated in Paraná. In 1878, the indigenous Kaingang, some of them coming from the Capuchin settlements (Mota and Novak 2008:68), retook to their old territories in the valley of Marrecas river. The Indigenous 
Land of Marrecas was the first area reserved for an indigenous group in Paraná. "Despite the reduction that occurred in 1949, it is proof that even after so many policies contrary to the interests of the Indians, developed by the state and by local elites, the latter were not able to extinguish the Kaingang of the Koran-bang-rê, who kept part of their former territories in the current Indigenous Land of Marrecas" (Mota; Novak 2008:94)

This shows that even with the miscegenation project and plundering of their lands, the Indians knew how to use political strategies and negotiated the return and demarcation of their territories in the context that was presented to them.

It was not only the Spanish Jesuit missionaries of the colony and the Capuchin Empire who had to adapt the catechesis and in order to survive in the 'new world'. Says Oliveira (2003:192), experience in the Guairenha region allowed for the development of a hybrid Christianity in which elements of European culture coexisted with that of the Amerindian, but not without conflicts.

The religious enterprise that entered the lives of the indigenous of territory, the encounter not only of European religion with indigenous cosmology, but also of two different worlds, generated ethnogenesis processes. On the concept of ethnogenesis, the anthropologist Miguel Alberto Bartolomé (2006) states that "ethnogenesis, or rather the ethnogeneses refer to the dynamism inherent in ethnic groups whose social logics reveal a plasticity and adaptive capacity that were not always recognized by anthropological analysis "(Bartolomé 2006:40).

Ethnogenesis was and is a constant historical process that reflects the cultural and political dynamics of the societies that were anterior to and marginalized from the development of today's nation-states. So ethnogenesis is the basic process of creating and structuring of human cultural diversity, "ethnogenesis is an integral part of the historical process of humanity and not only a datum of the present" (Bartolomé 2006: 41).

Understanding ethnogenesis is to understand the creation of political spaces for the affirmation of identity and the search for collective rights. In line with this way of thinking, ethnogenesis is a concept that "allows us to explore the cultural creativity of indigenous peoples and non-indigenous, such as the development of new political and interpretive spaces that allow people and groups to build enduring social identities while shaping their future in the context of globalizating nation-states of Latin America" (Hill 2013: 61).

So ethnogeneses is the product of this historical process of contact initiated in the Jesuit missions of the seventeenth century in the territory posteriorly called of State of 
Paraná. A response to colonial discourse, reversing it, deconstructing it, showing that the Indian is subject within the colonial past and present struggles. Showing that the groups reinterpret the situation of contact, reworking it into a network of strategies, negotiations, translations and mergers.

\section{References:}

Ambrosetti, Juan B. 1895. "Los indios Kaingangues de San Pedro (Missiones)". In: Revista Del Jardin Zoológico de Buenos Aires. Tomo II, Ent 10, p 305-387. Buenos Aires.

Amoroso, Marta. 2014. Terra de Índio: Imagens em Aldeamentos do Império. São Paulo: Terceiro Nome.

Bartolome, Miguel Alberto. 2006. "As etnogêneses: velhos atores e novos papéis no cenário cultural e político". In: Revista Mana. Vol.12, n.1, p. 39-68. Rio de Janeiro: PPGAS-Museu Nacional.

Bhabha, Homi K. 2005. "A outra questão: o estereótipo, a discriminação e o discurso colonial”. In: O local da cultura. Belo Horizonte: EDUFMG.

Borba, Telêmaco M. 1908. Actualidade Indígena. Curitiba: Tipografia a Vapor Impressora Paranaense.

Carneiro da Cunha, Manuela. 1992. Legislação Indigenista no século XIX. Edusp, Comissão Pró-Índio de São Paulo, São Paulo, 1992.

. "Política indigenista no século XIX". In: História dos índios no Brasil. (Carneiro da Cunha, Org.) São Paulo: Companhia das Letras.

Damo, Jandir. 1992. Guayrá, no antigo Paraguay: uma história de indios, colonos e missionários. São Leopoldo: UNISINOS. Dissertação de Mestrado.

Farage, Nádia and Carneiro da Cunha, Manuela. 1987. "Caráter da Tutela dos Índios: Origens e Metamorfoses". In: Os Direitos do Índio. Ensaios e Documentos (Carneiro da Cunha, Org.). São Paulo, Editora Brasiliense. 
Hill, Jonathan. 2013. "Etnicidade na Amazônia Antiga: reconstruindo identidades do passado por meio da arqueologia, da linguística e da etno-história". In: Ilha Revista de Antropologia, v. 15, n. 1, p. 35-70, Florianópolis.

MCA I (Manuscritos da Coleção de Angelis I). 1951. Jesuitas e bandeirantes no Guairá (15491640). Introdução por Jaime Cortesão. Rio de Janeiro: Biblioteca Nacional.

Monteiro, John Manuel. 1994. Negros da Terra: Índios e bandeirantes nas origens de São Paulo. São Paulo: Companhias das Letras.

Montoya, Antonio Ruiz. 1985. Conquista espiritual feita pelos religiosos da Companhia de Jesus nas Províncias do Paraguai, Paraná, Uruguai e Tape. Porto Alegre: Martins Livreiro Ed.

Moreira Neto, Carlos de Araújo. 2005 [1972]. Os índios e a Ordem Imperial. Brasília: Ministério da Justiça/Funai.

Mota, Lucio and Novak, Eder da Silva. 2008. Os Kaingang do vale do rio Ivaí PR: história e relações interculturais. 1. ed. Maringá: EDUEM.

Necker, Louis. 1990. Indios Guaranies y chamanes franciscanos: las primeras reducciones del Paraguay (1580-1800). Asunción: Centro de Estudios Antropológicos/Universidad Católica.

Parellada, Claudia Inês. 2009. "O Paraná espanhol: cidades e missões jesuíticas no Guairá". In: Missóes: conquistando almas e territórios, p.59-79. Curitiba:Secretaria de Estado da Cultura do Paraná (org).

Parellada, Claudia Inês. Arte e espacialidade nas cidades coloniais espanholas (1554-1632) e nas missões jesuíticas do Guairá(1610-1631). Revista Memorare. V.1, n.1.

Tubarão:GRUPEP-UNISUL. Http:

//http://www.portaldeperiodicos.unisul.br/index.php/memorare_grupep/article/view/1906

Oliveira, Oséias de. 2003. Índios e jesuítas no Guairá: a redução como espaço de reinterpretação cultural (século XVII). Assis: Tese de Doutorado - Faculdade de Ciências e Letras de Assis Universidade Estadual Paulista.

Taunay, Afonso. 1925. Documentação espanhola. Anais do Museu Paulista, tomo II, $2^{\mathrm{a}}$ parte, São Paulo, Officinas do Diário Official. 
Eurich, Grazieli. The colonial discourse of domination: notes on the Christian religious contact among the indigenous or Paraná, Brazil.

Viveiros de Castro, Eduardo. 2002. “O Mármore e a Murta: sobre a inconstância da Alma Selvagem". In: A Inconstância da Alma Selvagem e Outros Ensaios de Antropologia. São Paulo: Cosac \& Naify. 552 pp. 